\title{
Pengaruh Pembelajaran Fisika Pokok Bahasan Cahaya dengan Model Guided Discovery Learning Terhadap Kemampuan Kognitif Peserta Didik Kelas VIII SMP
}

\author{
Aulia Afifatur Rasyidah ${ }^{1}$, Widayanti ${ }^{2}$ \\ 1,2 Program Studi Pendidikan Fisika, UIN Sunan Kalijaga Yogyakarta \\ Jl. Laksda Adisucipto, Papringan, Caturtunggal, Kec. Depok, Kabupaten Sleman, Daerah Istimewa \\ Yogyakarta 55281 \\ Email : auliaafifatur@gmail.com
}

\begin{abstract}
This research aims 1). To determine the effect of guided discovery learning models on students's cognitive abilities 2). Knowing the difference in students's cognitive abilities between the experimental class and control class. This research is a quasi-experimental research with nonequivalent control group design. The independent variable is guided discovery learning model while the dependent variable is the cognitive ability of students. The sampling technique uses saturated sampling technique because the research subjects are all students of class VIII of SMP Muhammadiyah Purwojati in the 2018/2019 academic year. The instruments used in the form of learning tools, question sheets, and observation sheets. The question sheets is used to obtain data on students's cognitive abilities and observation sheet is used to obtain data about the activities of students in participating in learning using guided discovery learning model. Data on students's cognitive abilities were analyzed by descriptive statistics with quantitative methods. the results showed that there was influence of guided discovery learning model. on the cognitive abilities of students as evidenced by the experimental class mean value of 70.32 higher than the control class of 43.27 and there was increase in cognitive ability in the experimental class with an $N$-Gain value 0,67 (moderate) higher than the control class with $\mathrm{N}$-Gain of 0.35 (moderate) with an effect size value of 1.80 (very significant).
\end{abstract}

Keywords: Light, Guided Discovery Learning, Cognitive Ability.

Abstrak: Penelitian ini bertujuan 1). untuk mengetahui pengaruh model pembelajaran guided discovery learning terhadap kemampuan kognitif peserta didik 2). Mengetahui perbedaan peningkatan kemampuan kognitif peserta didik antara kelas eksperimen dan kelas kontrol. Penelitian ini adalah penelitian eksperimen semu dengan nonequivalent control grup design. Variabel bebas berupa model pembelajaran guided discovery learning sedangkan variabel terikat berupa kemampuan kognitif peserta didik. Teknik pengambilan sampel menggunakan teknik sampling jenuh karena subyek penelitiannya adalah semua peserta didik kelas VIII SMP Muhammadiyah Purwojati tahun pelajaran 2018/2019. Instrumen yang digunakan berupa perangkat pembelajaran, lembar soal uraian dan lembar observasi. Lembar soal digunakan untuk memperoleh data kemampuan kognitif peserta didik dan lembar observasi digunakan untuk memperoleh data tentang aktivitas peserta didik dalam mengikuti pembelajaran dengan menggunakan model guided discovery learning. Data kemampuan kognitif siswa dianalisis dengan statistik deskriptif metode kuantitatif. Hasil penelitian menunjukkan bahwa terdapat pengaruh model pembelajaran guided discovery learning terhadap kemampuan kognitif peserta didik dibuktikan dengan nilai mean kelas eksperimen sebesar 70,32 lebih tinggi dibandingkan kelas kontrol sebesar 43,27 dan terdapat peningkatan kemampuan kognitif pada kelas eksperimen dengan nilai $\mathrm{N}$ Gain sebesar 0,67 (sedang) lebih tinggi dibandingkan kelas kontrol dengan N-Gain sebesar 0,35 (sedang) dengan nilai effect size sebesar 1,80 (sangat signifikan).

Kata kunci: Cahaya, Guided Discovery Learning, Kemampuan Kognitif 


\section{PENDAHULUAN}

Peraturan Menteri Pendidikan Nasional tahun 2006 menjelaskan bahwa IPA, termasuk fisika bukan hanya berisi pengetahuan, tetapi juga proses penemuan. Maka dalam pembelajaran peserta didik perlu lebih banyak menemukan, dengan diberi pengalamanpengalaman langsung dalam hidup sehari-hari. Jelas disini bahwa hakikat IPA bukan hanya sebagai produk pengetahuan tetapi juga sebagai proses (Suparno, 2009: 75). Dengan kata lain, dalam belajar peserta didik harus aktif mengolah bahan, mencerna, memikirkan, menganalisis dan akhirnya yang terpenting merangkumnya sebagai suatu pengertian yang utuh. Tanpa keaktifan peserta didik dalam membangun pengetahuan mereka sendiri, mereka tidak akan mengerti apa-apa (Suparno, 2013: 15).

Permasalahan yang terjadi dalam pembelajaran fisika saat ini adalah guru kurang memberikan kesempatan kepada peserta didik untuk aktif dalam pembelajaran sehingga tidak terlibat dalam proses penemuan. Proses pembelajaran di dalam kelas diarahkan pada kemampuan anak untuk menghafal informasi (Sanjaya, 2006: 1). Metode pengajaran tradisional lebih menekankan pada penyediaan konten daripada pengembangan ketrampilan berpikir peserta didik, yang perlu dikembangkan oleh guru adalah membantu peserta didik bukan hanya dalam menambah pengetahuan peserta didik tetapi juga mengembangkan ketrampilan mereka terhadap pemahaman konsep, menganalisis, menginterprestasi, dan befikir kritis peserta didik (Smitha,dkk,, 2011: 23). Guru memerlukan model pembelajaran yang mampu mengoptimalkan kemampuan berfikir peserta didik, memberi kesempatan peserta didik terlibat dalam proses penemuan.

Materi yang dirasa sulit oleh guru menurut hasil wawancara adalah materi cahaya (optik geometri), guru mengalami kesulitan saat menjelaskan konsep pembentukan bayangan dan menjelaskan perbedaan bayangan semu dan nyata kepada peserta didik. Menjelaskan konsep tersebut, peserta didik membutuhkan pengalaman secara langsung seperti melakukan percobaan yang mampu mendorong peserta didik untuk menemukan konsep sendiri mengenai bayangan semu dan nyata sehingga peserta didik dapat membangun sendiri pengetahuannya. Salah satu model pembelajaran yang melibatkan proses penemuan adalah model pembelajaran guided discovery learning. Model pembelajaran guided discovery learning merupakan model pembelajaran yang memotivasi peserta didik lebih aktif dalam proses pembelajaran dan membantu mereka dalam mendalami pemahaman konsep (kartikaningtyas,dkk., 2017: 2). Pada model pembelajaran guided discovery learning, kegiatan pempelajaran pada model tersebut mengharuskan peserta didik untuk melakukan penyelidikan dan mengeksplorasi materi yang dapat membantu peserta didik dalam menemukan suatu konsep atau yang berkaitan dengan materi pembelajaran. Oleh karena itu peserta didik tidak dihadapkan dengan konsep tetapi peserta didik sendiri yang diminta untuk merumuskan konsep (Wulandari,dkk., 2018: 2). Model pembelajaran guided discovery learning, peserta didik tidak diharuskan menemukan sesuatu yang benar-benar baru, tetapi peserta didik diharapkan untuk menemukan pengetahuan dengan melakukan kegiatan untuk menemukan konsep, persamaan, dan sejenisnya dengan bimbingan guru (Amiyani dan Widjajanti, 2018:1)

Hasil belajar dengan penerapan model pembelajaran guided discovery learning telah dibuktikan oleh Hendra, dkk tahun 2016. Hasil yang diperoleh dari penelitiannya adalah nilai rata-rata tes prestasi kognitif yang diberi pelakuan dengan model guided discovery sebesar 61,74; sedangkan kelas yang diberikan perlakuan dengan model direct instruction nilai tes prestasi kognitifnya sebesar 52,79. Ini menunjukkan bahwa penerapan model pembelajaran guided discovery lebih membantu peserta didik untuk menemukan dan mengembangkan fakta dan konsepnya sendiri dan memfasilitasi peserta didik dalam proses pembelajaran sehingga dapat meningkatkan kemampuan kognitif fisika dibandingkan model pembelajaran direct 
instruction. Sejalan dengan penelitian Hendra, dkk, penelitian yang dilakukan oleh Achera,dkk tahun 2015 menunjukan bahwa hasil belajar dengan menggunakan model pembelajaran guided discovery learning lebih tinggi dari pada model pembelajaran konvensional pada materi geometri.

Tujuan penelitian ini adalah untuk mengetahui pengaruh model pembelajaran guided discovery learning terhadap kemampuan kognitif peserta didik serta mengetahui perbedaan peningkatan kemampuan kognitif peserta didik antara kelas eksperimen dan kelas kontrol

\section{METODE PENELITIAN}

Jenis penelitian ini adalah kuasi eksperimen (eksperimen semu) dengan desain penelitian berupa Nonequivalent Control Group Design dimana kelompok eksperimen dan kelompok kontrol tidak dipilih secara random (Sugiyono, 2013: 116). Kedua kelompok tersebut diberikan pretest dengan tujuan untuk mengetahui keadaan awal kedua kelompok tersebut. Selanjutnya kelompok eksperimen diberi perlakuan pada pembelajaran fisika berupa pembelajaran dengan model guided discovery learning sedangkan kelas kontrol diberi perlakuan berupa pembelajaran fisika dengan model direct instruction. Setelah itu kedua kelompok tersebut diberi posttest untuk mengetahui hasil setelah diberi perlakuan.

Populasi dalam penelitian ini adalah kelas VIII tahun ajaran 2019 di SMP Muhammadiyah Purwojati. Jumlah kelas VIII pada sekolah tersebut hanya terdapat dua kelas sehingga teknik pengambilan sampel dalam penelitian ini menggunakan Nonprobability Sampling yaitu sampling jenuh. Sampling jenuh adalah teknik penentuan sampel bila semua anggota populasi digunakan sebagai sampel (Sugiyono, 2013: 124). Berdasarkan dari penjelasan tersebut terpilih kelas VIIIA dan VIIIB sebagai sampel sekaligus populasi dalam penelitian ini.

Variabel bebas dalam penelitian ini adalah model pembelajaran fisika guided discovery learning sedangkan variabel terikat dalam penelitian ini adalah kemampuan kognitif peserta didik. Instrumen yang digunakan dalam penelitian ini adalah instrumen pembelajaran, lembar observasi dan instrumen tes berupa soal kemampuan kognitif peserta didik. Sebelum digunakan dalam penelitian, instrumen soal dan instrumen pembelajaran diuji validitas isi dan konstruksinya sedangkan instrumen observasi kegiatan pembelajaran hanya diuji validitas konstruksinya saja, validasi tersebut dilakukan dengan cara meminta masukan dan pertimbangan para ahli (expert judgment). Hasil penilaian dari para ahli diolah menggunakan formula $V$ Aiken. Formula persamaannya adalah sebagai berikut (Azwar, 2012: 113) :

$$
V=\frac{\sum S}{\left[n_{i} *(c-1)\right]} \text { dengan } S=r-I_{0}
$$

dengan $V$ adalah indeks validitas isi $n_{i}$ adalah banyaknya rater (penilai) $c$ adalah banyaknya kategori kriteria yang di nilai $I_{0}$ kategori terendah dan $r$ adalah kriteria ke 1 yang dinilai. Suatu instrumen dapat diakatakan valid apabila nilai $V$ Aiken yang diperoleh tersebut lebih besar atau sama dengan $0,6(\geq 0,6)$.

Teknik Analisa data yang digunakan dalam penelitian ini adalah analisis deskriptif. Analisis deskriptif adalah analisis yang digunakan untuk mendeskripsikan atau memberi gambaran terhadap obyek yang diteliti melalui data sampel atau populasi (Sugiyono, 2007: 29). Analisis deskriptif yang digunakan dalam penelitian ini adalah penyajian data yang berupa tabel, tendensi sentral, ukuran dispersi, dan ukuran letak.

Ukuran tandensi sentral merupakan ukuran yang digunakan untuk mengetahui pemusatan data distribusi kemampuan kognitif peserta didik pada kelas eksperimen dan kelas kontrol 
baik sebelum diberikan perlakuan maupun sesudah diberikan perlakuan. Ukuran tandensi sentral yang digunakan dalam penelitian ini hanya rerata atau mean. Nilai rerata atau mean dapat dicari dengan menggunakan persamaan (2)

$$
M_{e}=\frac{\sum X_{i}}{n}
$$

dengan $M_{e}$ adalah mean (rata-rata), $\sum$ adalah epsilon ( baca jumlah), $X_{i}$ adalah nilai $x$ ke $i$ sampai ke $n$ dimana $\mathrm{n}$ adalah jumlah individu.

Ukuran dispersi merupakan ukuran yang digunakan untuk mengetahui besarnya penyimpangan/ penyebaran distribusi data nilai kemampuan kognitif peserta didik terhadap sentralnya.Ukuran dispersi yang digunakan dalam penelitian ini hanya standar deviasi. Nilai standar deviasi dapat dicari dengan menggunakan persamaan (3)

$$
s=\sqrt{\frac{\sum\left(X_{i}-\bar{X}\right)^{2}}{n}}
$$

dengan $s$ adalah standar deviasi, $X_{i}$ adalah data pengukuran, $\bar{X}_{\text {adalah rata-rata data serta } n}$ adalah jumlah data.

Ukuran letak merupakan ukuran yang digunakan untuk untuk mengetahui sejauh mana proses pencapaian kemampuan kognitif peserta didik berhasil. Ukuran letak yang digunakan dalam penelitian ini adalah kuartil. Nilai kuartil dapat dicari dengan menggunakan persamaan (4)

$$
K_{1}=\frac{i(n+1)}{4}
$$

dengan $K_{i}$ adalah nilai kuartil, $i$ adalah kuartil ke-, sedangkan $n$ adalah jumlah data.

Model pembelajaran guided discovery learning dikatakan dapat berpengaruh dalam penelitian ini apabila nilai rata-rata kemampuan kognitif setelah diberi perlakuan dan peningkatan kemampuan kognitif peserta didik pada kelas eksperimen lebih tinggi dibandingkan dengan kelas kontrol. Peningkatan kemampuan kognitif peserta didik dapat diketahui melalui persamaan (5) dan kriterianya ditunjukkan oleh tabel 1.

$$
\mathrm{N}-\text { Gain }=\frac{\text { Posttest score-Pretest score }}{\text { Maximumpossible score-Pretest score }}
$$

Tabel 1. Klasifikasi N-Gain (Hake, 1998)

\begin{tabular}{ccc}
\hline No & $\begin{array}{c}\text { Rata-rata } N \text {-Gain } \\
\text { Ternormalisasi }\end{array}$ & Klasifikasi \\
\hline 1. & $0.70<$ N-gain $\leq 1,00$ & Tinggi \\
2. & $0,30<\mathrm{N}$-gain $\leq 0,70$ & Sedang \\
3. & N-gain $\leq 0,30$ & Rendah \\
\hline
\end{tabular}

Jika kedua kelas memperoleh level peningkatan yang sama, maka untuk menghitung perbedaannya dapat dilakukan dengan perhitungan Effect Size. Effect size merupakan nilai yang menyatakan seberapa besar perbedaan hasil antara kelas eksperimen dengan kelas 
kontrol setelah diberi perlakuan (Thalhaimer, 2002). Nilai effect size dapat dicari dengan menggunakan persamaan (6) dan kriterianya ditunjukkan oleh tabel 2.

$$
d=\frac{M_{2}-M_{1}}{\sqrt{\frac{s_{1}^{2}+s_{2}^{2}}{2}}}
$$

dengan $M_{2}$ adalah rerata kelompok eksperimen, $M_{1}$ adalah rerata kelompok kontrol, $\mathrm{S}_{1}{ }^{2}$ adalah varians kelompok eksperimen serta $\mathrm{S}_{2}{ }^{2}$ adalah varians kelompok kontrol.

Tabel 2. Kategori Effect Size (Lee A Becker, 2000)

\begin{tabular}{cccc}
\hline No & $\mathrm{D}$ & Kategori & Keterangan \\
\hline 1. & $\mathrm{~d} \geq 0,8$ & Tinggi & $\begin{array}{c}\text { Perbedaan peningkatan } \\
\text { sangat signifikan } \\
\text { Perbedaan peningkatan } \\
\text { cukup signifikan }\end{array}$ \\
3. & $0,5 \leq d<0,8$ & Sedang & $\begin{array}{c}\text { Perbedaan peningkatan } \\
\text { tidak signifikan }\end{array}$ \\
\hline
\end{tabular}

\section{HASIL DAN PEMBAHASAN}

Data hasil kemampuan kognitif peserta didik diperoleh melalui tes berupa soal uraian dengan jumlah delapan soal yang digunakan untuk pretest dan posttest. Pretest pada kelas eksperimen dilakukan pada tanggal 29 April 2019 sedangkan pada kelas kontrol dilakukan pada tanggal 30 April 2019. Postest pada kelas eksperimen dan kelas kontrol dilaksanakan pada tanggal 14 Mei 2019. Data Pretest dan Posttest selanjutnya dianalisis menggunakan analisis deskriptif. Hasil pretest dan posttest pada kelas eksperimen dan kelas kontrol ditunjukkan pada tabel 3.

Tabel 3. Hasil Rata-Rata Kemampuan Kognitif

\begin{tabular}{cccc}
\hline No & Kelas & Pretest & Posttest \\
\hline 1. & Kontrol & 12.18 & 43.27 \\
2. & Eksperimen & 7.86 & 70.32 \\
\hline
\end{tabular}

Berdasarkan tabel 3 peningkatan nilai rata-rata kemampuan kognitif peserta didik setelah diberi perlakuan model guided discovery learning pada kelas eksperimen cenderung lebih tinggi dibandingkan dengan kelas kontrol yang diberi perlakuan dengan menggunakan model pembelajaran direct instruction. Pada kelas eksperimen yang nilai awalnya 7,86 meningkat menjadi 70,32 sedangkan pada kelas kontrol yang nilai awalnya 12,18 menjadi 43,27.

Trianto (2007:106) mengemukakan bahwa proses pembelajaran pada dasarnya menekankan pentingnya peserta didik membangun sendiri pengetahuan mereka melelaui keterlibatan aktif proses pembelajaran. Penekanan belajar peserta didik perlu dikembangkan, kreatifitas dan keaktifan peserta didik akan membantu mereka untuk berdiri sendiri dalam kehidupan kognitif peserta didik.

Pada model pembelajaran guided discovery learning peserta didik membangun sendiri pengetahuannya dari tahap motivation and problem presentation, guru memberikan masalah dalam bentuk pernyataan dan peserta didik diminta untuk mengenali masalah yang diberikan oleh guru. Pada tahap selection of learning activities, peserta didik diminta untuk memilih 
beberapa identifikasi masalah yang akan dibuktikan, selanjutnya pada tahap data collection dan data processing pada tahap ini peserta didik diminta untuk mengumpulkan data melalui sebuah percobaan yang selanjutnya dianalisis hasilnya dan dari analisis hasil percobaan selanjutnya peserta didik dituntut menyimpulkan hasil percobaan pada tahap closure. Dari kesimpulan tersebut peserta didik membangun konsep atau memperoleh fakta yang berakaitan dengan materi pembelajaran. Model pembelajaran guided discovery learning menuntut lebih banyak aktivitas peserta didik dalam pembelajaran sedangkan guru hanya sebagai fasilitator.

Pada model pembelajaran direct instruction, peserta didik tidak dituntut untuk membangun pengetahuannya sendiri. Semua kebenaran diterima oleh peserta didik melalui penyajian yang disampaikan oleh guru. Tahapan pembelajaran direct instruction yang dilakukan oleh guru yaitu penyampaian materi yang dilakukan oleh guru, memberikan contoh soal dan bimbingan latihan dan peserta didik menanyakan materi yang belum dipahami. Model pembelajaran direct instruction, guru lebih aktif dalam proses pembelajaran dan peserta didik hanya memperhatikan apa yang disampaikan oleh guru.

Berdasarkan tabel 4 bahwa penyimpangan terhadap nilai rata-rata kemampuan kognitif peserta didik sebelum diberi perlakuan pada kelas kontrol sebesar 7,63 sedangkan pada kelas eksperimen sebesar 5,36. Setelah diberikan perlakuan nilai penyimpangan terhadap kemampuan kognitif peserta didik baik kelas eksperimen maupun kelas kontrol mengalami peningkatan. Pada kelas eksperimen yang awalnya nilai penyimpangannya sebesar 5,36 setelah diberikan perlakuan menjadi 17,07. Sedangkan pada kelas kontrol yang awalnya nilai penyimpangannya sebesar 7,63 setelah diberi perlakuan menjadi 12,65. Penyimpangan terhadap nilai rata-rata pada kelas eksperimen cenderung lebih tinggi dibandingkan dengan kelas kontrol hal tersebut menunjukan kemampuan kognitif siswa setelah diberikan perlakuan pada kelas eksperimen cenderung lebih heterogen dibandingkan kelas kontrol (Himawan, 2018).

Tabel 4. Hasil Standar Deviasi Kemampuan Kognitif

\begin{tabular}{cccc}
\hline No & Kelas & Pretest & Posttest \\
\hline 1. & Kontrol & 7,63 & 12,65 \\
2. & Eksperimen & 5,36 & 17,07 \\
\hline
\end{tabular}

Ukuran letak ketiga kuartil tersebut membagi data menjadi empat bagian. Berdasarkan tabel 5 menunjukan bahwa masing-masing nilai ukuran letak pada kedua kelas tersebut mengalami peningkatan. Pada kelas eksperimen cenderung lebih tinggi dibandingkan dengan kelas kontrol. Bisa dilihat bahwa nilai (Q2) pada kelas eksperimen setelah diberikan perlakuan nilai yang awalnya sebesar 11,00 meningkat menjadi 76,00. Sedangkan pada kelas kontrol yang awalnya nilainya sebesar 16.00 meningkat menjadi 39,00. Hal tersebut menunjukan bahwa pada kelas eksperimen terdapat 50\% peserta didik mendapatkan nilai diatas 76,00 (lebih dari nilai batas KKM), sedangkan pada kelas kontrol terdapat 50\% siswa mendapatkan nilai masih dibawah nilai batas KKM. Hal tersebut menjelaskan bahwa pencapaian kemampuan kognitif kelas eksperimen lebih tinggi dibandingkan dengan kelas kontrol.

Tabel 5. Ukuran Letak Kemampuan Kognitif

\begin{tabular}{|c|c|c|c|c|c|c|c|}
\hline \multirow{2}{*}{ No } & \multirow{2}{*}{ Kelas } & \multicolumn{3}{|c|}{ Pretest } & \multicolumn{3}{|c|}{ Posttest } \\
\hline & & $Q 1$ & $Q 2$ & $Q 3$ & $Q 1$ & $Q 2$ & $Q 3$ \\
\hline 1 & Kontrol & 5,75 & 16,00 & 18,00 & 37,00 & 39,00 & 45,00 \\
\hline 2 & Eksperimen & 5,00 & 11,00 & 11,00 & 68,00 & 76,00 & 79,00 \\
\hline
\end{tabular}


Tabel 6. Nilai N-Gain Kemampuan Kognitif Siswa

\begin{tabular}{cccccc}
\hline No & Kelas & Terendah & Tertinggi & Rata-Rata & Klasifikasi \\
\hline 1 & Kontrol & 0,15 & 0,80 & 0,35 & Sedang \\
2 & Eksperimen & 0,24 & 0,92 & 0,67 & Sedang \\
\hline
\end{tabular}

Berdasarkan tabel 6 rata-rata $N$-Gain pada kelas eksperimen adalah 0,67 dan masuk dalam kriteria sedang. Pada kelas kontrol, rata-rata $N$-Gain sebesar 0,35 sehingga masuk dalam kriteria sedang. Walaupun masuk dalam kriteria yang sama, tetapi rata-rata nilai $\mathrm{N}$-Gain kelas eksperimen lebih tinggi daripada kelas kontrol. Sehingga untuk mengetahui perbedaan peningkatan kemampuan kognitif antara kedua kelas tersebut dilakukan analisis effect size yang disajikan pada tabel 7 .

Tabel 7. Data Hasil Effect Size Kelas Eksperimen dan Kontrol

\begin{tabular}{lllll}
\hline No & Kelas & Rata-Rata $N$-Gain & Effect Size & Keterangan \\
\hline 1. & Kontrol & 0,35 & \multirow{2}{*}{1,80} & Sangat \\
2. & Eksperimen & 0,65 & Signifikan \\
\hline
\end{tabular}

Berdasarkan tabel 7 dapat dilihat bahwa nilai effect size diperoleh nilai sebesar 1,80 pada kategori tinggi. Menurut Lee A. Beker $(2003: 3)$ kategori tinggi jika nilai koefesien cohen $d$ yang diperoleh lebih atau sama dengan 0,8 . Nilai effect size pada tabel 7 dapat menunjukan bahwa perbedaan peningkatan kemampuan kognitif pada kedua kelas sangat signifikan dengan peningkatan yang lebih tinggi pada kelas eksperimen yang diberikan perlakuan dengan model pembelajaran fisika guided discovery learning dibandingkan dengan kelas kontrol yang diberikan perlakuan model pembelajaran direct instruction.

Berdasarkan tabel 3 dan tabel 6 menunjukan bahwa nilai rata-rata kemampuan kognitif peserta didik setelah diberikan perlakuan dan nilai peningkatan kemampuan kognitif pada kelas eksperimen cenderung lebih tinggi dibandingkan dengan kelas kontrol. Nilai rata-rata posttest kelas eksperimen sebesar 70,32 dengan nilai rata-rata peningkatan kemampuan kognitif sebesar 0,67. Sedangkan pada kelas kontrol nilai rata-rata posttest sebesar 43,27 dengan nilai rata-rata peningkatan kemampuan kognitif sebesar 0,35 . Perbedaan tersebut menunjukan bahwa pembelajaran guided discovery learning lebih baik dari pada model pembelajaran direct instruction dalam meningkatkan kemampuan kognitif peserta didik. Penemuan yang ditemukan dalam penelitian ini sejalan dengan penelitian yang dilakukan oleh Hendra,dkk., bahwa nilai prestasi kognitif peserta didik dengan menggunakan model pembelajaran guided discovery learning lebih baik dibandingkan dengan menggunakan model pembelajaran direct instruction.

\section{KESIMPULAN}

Model pembelajaran guided discovery learning memberikan pengaruh terhadap kemampuan kognitif peserta didik kelas VIII SMP Muhammadiyah Purwojati pada pokok bahasan cahaya. Hal ini dapat diketahui melalui pemerolehan nilai rata-rata kemampuan kognitif peserta didik pada kelas eksperimen setelah diberi perlakuan lebih tinggi dibandingkan dengan kelas kontrol, pada kelas eksperimen nilai rata-rata kemampuan kognitif peserta didik sebesar 70,32 sedangkan pada kelas kontrol nila rata-rata kemampuan kognitif peserta didik sebesar 43,27. Pengaruh model pembelajaran guided discovery learning juga dibuktikan dengan adanya pencapaian peningkatan kemampuan kognitif peserta didik pada kelas eksperimen cenderung lebih tinggi dibanding kelas kontrol

Pembelajaran menggunakan model guided discovery learning mampu meningkatkan kemampuan kognitif peserta didik pada pokok bahasan cahaya. Hal ini dapat diketahui melalui nilai $\mathrm{N}$-Gain rata rata sebesar 0,67 atau masuk dalam kategori sedang. Adapun pada kelas kontrol juga terdapat peningkatan kemampuan kognitif pada kategori sedang setelah 
diberikan treatment berupa model pembelajaran direct instruction ditunjukkan dengan nilai $\mathrm{N}$-Gain rata-rata sebesar 0,35. Peningkatan kemampuan kognitif peserta didik kelas eksperimen dan kelas kontrol keduanya berada pada kategori sedang tetapi memiliki perbedaan yang sangat signifikan ditunjukkan dengan nilai effect size sebesar 1,80.

\section{SARAN}

Bagi peneliti selanjutnya yang akan menggunakan model pembelajaran guided discovery learning terhadap kemampuan kognitif siswa disarankan ditambahkan variabel lainya seperti ketrampilan proses sains siswa

\section{DAFTAR PUSTAKA}

Achera, L.J., Belecina, R.R., \& Garvida, M.D. (2015). The Effect of Group Guided Discovery Approach on the Perfomance of Students in Geometri. Interntional Journal of Multidisplinary Research and Modern Education 1 p 332-333.

Amiyani, R., \& Widjajanti, J.B. (2018). The Excellence of Guided Discovery Learning on Mathematical Knowledge-Based, Skill-Based, Skill- Based, and Attitude. Journal of Physics. Series 1097 (2018) 012145. doi:10.1088/1742-6596/1097/1/012145.

Azwar, S. (2012). Raebilitas dan Validitas. Yogyakarta: Pustaka Pelajar.

Becker, L. A. (2000). Effect Size

Hake, R. (1998). Interactive-Engagement Versus Traditional Metode: A Six ThousandStudent Survey Of Mechanics Test Data For Introductory Physics Courses. American Journal of physics , I (66), 67-74.

Himawan, N.A., \& Winarti. (2018). Strategi Metakognisi untuk Meningkatakan Kemampuan Pemecahan Masalah pada Materi Teori Kinetik Gas. Edusains, 265-274

Kartikaningtyas, V., Kusmayadi, T.A., \& Riyadi. (2017). Contextual Approach with Guided Discovery Learning and Brain Based Learning in Geometry Learning. Journal of Physics. Series 895 (2017) 012024. doi : 10.1088/1742-6596/895/012024.

Purnomo, H.Y., Mujasam, \& Yusuf, I .(2016). Penerapan Model Guided Discovery Learning Pada Materi Kalor Terhadap hasil belajar Kognitif Peserta Didik Kelas VII SMP Prafi Manokwari Jawa Barat. Journal Pancaran.

Sanjaya, W. (2006). Strategi Pembelajaran Berorientasi Standar Proses Pendidikan. Jakarta: Kencana Pernada Media Group.

Smitha, V.P., \& Manjula, P. R. (2011). Relative Efectiveness of Inquiry Training Model and Guided Discovery Learning on Critical Thinking of Secondary School Students.Journal of Indian Education.

Sugiyono. (2007). Statistika untuk Penelitian.Bandung : Alfa Beta.

Sugiono. (2013). Metode Penelitian Pendidikan. Bandung : Alfa Beta.

Suparno, P. (2009). Kajian Kurikulum Fisika SMA/MA Berdasarkan KTSP. Yogyakarta: Universitas Sanata Dharma

Suparno, P. (2013). Metodologi Pembelajaran Fisika. Yogyakarta: USD

Thalheimer. (2002). How to calculate effect sizes. A Work-Learning Research Publication.

Trianto. (2007). Model-Model Pembelajaran Inovatif Berorientasi Konstruktivistik. Jakarta: Prestasi Pustaka.

Wulandari, I,G.A.P., Sa'dijah, C., As'ari, A.R., \& Rahardjo, S.(2018). Modified Guided Discovery Model : A Conceptual Framework for Designing Learning Model Using Guided Discovery to Promote Student's Analytical Thinking Skiils. Journal of Physics.Series 1028 (2018) 012153. doi : 10.1088/ 1742-6596/1028/1/012153. 